\title{
PENGARUH BUDAYA ORGANISASI, KEADILAN ORGANISASIONAL, DAN MOTIVASI KERJA TERHADAP KOMITMEN ORGANISASIONAL
}

\author{
Komang Ririn Sindia Pratiwi ${ }^{1}$ \\ I Gusti Ayu Manuati Dewi \\ ${ }^{1,2}$ Fakultas Ekonomi dan Bisnis Universitas Udayana, Bali, Indonesia \\ 1email: sindiaririn23@gmail.com
}

\begin{abstract}
ABSTRAK
Tujuan dari penelitian ini adalah untuk menjelaskan pengaruh budaya organisasi, keadilan organisasional, dan motivasi kerja terhadap komitmen organisasional. Populasi dalam penelitian ini berjumlah 133 karyawan CV. Tirta Tamanbali. Penelitian ini dilakukan pada karyawan CV. Tirta Tamanbali yang dijadikan sebagai sampel penelitian. Ukuran sampel yang diambil sebanyak 100 responden dengan metode simple random sampling. Metode pengumpulan data dalam penelitian ini dilakukan dengan wawancara dan kuesioner. Teknik analisis yang digunakan adalah analisis regresi linear berganda. Hasil penelitian menunjukkan bahwa budaya organisasi, keadilan organisasional, dan motivasi kerja berpengaruh positif dan signifikan terhadap komitmen organsiasional. Hasil penelitian ini dapat memperkaya teori pertukaran sosial (social exchange theory) dan diharapkan dapat memberikan pengetahuan mengenai pengaruh budaya organisasi, keadilan organisasional, dan motivasi kerja terhadap komitmen organisasional. Penelitian ini diharapkan dapat memberikan kontribusi yang positif bagi pihak CV. Tirta Tamanbali untuk meningkatkan komitmen organisasional karyawan.
\end{abstract}

Kata kunci: komitmen organisasional, budaya organisasi, keadilan organisasional, motivasi kerja

\begin{abstract}
The purpose of this study is to explain the influence of organizational culture, organizational justice, and work motivation on organizational commitment. The population in this study amounted to 133 employees of CV. Tirta Tamanbali. This research was conducted on employees of $C V$. Tirta Tamanbali used as a research sample. The sample size taken was 100 respondents with the simple random sampling method. Data collection methods in this study were conducted by interview and questionnaire. The analysis technique used is multiple linear regression analysis. The results showed that organizational culture, organizational justice, and work motivation had positive and significant effects on organizational commitment. The results of this study can enrich social exchange theory (social exchange theory) and are expected to provide knowledge about the influence of organizational culture, organizational justice, and work motivation on organizational commitment. This research is expected to make a positive contribution to the CV. Tirta Tamanbali to increase employee organizational commitment.
\end{abstract}

Keywords: organizational commitment, organizational culture, organizational justice, work motivation 


\section{PENDAHULUAN}

Kemajuan teknologi dan persaingan yang ketat di era globalisasi ini menjadikan perusahaan akan selalu melakukan adaptasi terhadap perubahanperubahan yang terjadi pada lingkungan bisnis. Hal tersebut ditempuh dengan mengelola secara baik sumber-sumber daya yang ada di dalam perusahaan. Satusatunya sumber daya yang memiliki nilai kompetitif ialah sumber daya manusia (SDM), yang dimana faktor sumber daya manusia merupakan salah satu aspek penting yang ada di dalam perusahaan. SDM sebagai pelaksana setiap kegiatan operasional yang dijalankan untuk mencapai tujuan perusahaan yang diinginkan. SDM sangat penting untuk efektivitas perusahaan karena memainkan peran yang besar dalam mendukung keunggulan kompetitif perusahaan melalui karyawan yang berkomitmen (Zefeiti \& Mohamad, 2017)

Komitmen organisasional adalah keinginan kuat untuk tetap sebagai anggota organisasi, keinginan untuk berusaha keras sesuai keinginan organisasi, keyakinan tertentu, dan penerimaan nilai dan tujuan organisasi (Luthans, 2006:224). Rahman et al. (2015) menyatakan individu ketika menunjukkan komitmen terhadap organisasi mereka, cenderung akan tetap tinggal di organisasinya dan juga diharapkan untuk memberikan yang terbaik dalam mendukung organisasi mereka dan bekerja keras untuk keberhasilan dan kemakmurannya. Karyawan yang memiliki komitmen yang tinggi akan menunjukkan kesetiaannya terhadap perusahaan.

CV. Tirta Tamanbali merupakan perusahaan yang bergerak dalam bidang pengelolaan air. Perusahaan ini berstatus swasta nasional yang berdiri pada tahun 2003. Sebagai perusahaan yang bergerak pada bidang pengelolaan air, tentunya CV. Tirta Tamanbali merasa bahwa penting untuk memiliki karyawan dengan komitmen organisasional yang tinggi.

Ardana et al. (2012:52) mengemukakan bahwa rata-rata tingkat absensi 2-3 persen per bulan masih dianggap baik, sedangkan absensi 3 persen ke atas dianggap tidak wajar atau tergolong tinggi. Hubungan tingkat absensi karyawan dan komitmen organisasional dapat diartikan semakin banyak tingkat absensi karyawan, dapat menjadi indikasi rendahnya komitmen karyawan terhadap organisasi karena rendahnya keinginan karyawan untuk ikut terlibat dalam proses kegiatan dan pencapaian tujuan organisasi (Diputri \& Rahyuda, 2016). Hal serupa juga dinyatakan oleh Sintha (2013) yang menyatakan komitmen karyawan terhadap organisasi ditunjukkan dengan keterlibatannya secara aktif dalam organisasi untuk mencapai tujuan organisasi. Rata-rata tingkat absensi karyawan ditunjukkan pada Tabel 1.

Tabel 1.

Rata-rata Tingkat Absensi Karyawan CV. Tirta Tamanbali

\begin{tabular}{ccc}
\hline No & Tahun & Rata-rata tingkat absensi \\
\hline 1 & 2015 & 4,0 \\
2 & 2016 & 4,1 \\
3 & 2017 & 4,0 \\
4 & 2018 & 4,0 \\
5 & 2019 & 4,0 \\
\hline
\end{tabular}

Sumber: Data diolah, 2019 
Berdasarkan data pada Tabel 1. yang diperoleh dari Human Resource Departement (HRD) CV. Tirta Tamanbali terlihat bahwa tingkat absensi karyawan cukup tinggi. Hal ini dapat dilihat dari rata-rata absensi karyawan CV. Tirta Tamanbali tahun 2015-2019 seperti terlihat pada Tabel 1. Rata-rata Absensi Karyawan per bulan adalah di atas 3 persen. Absensi dengan rata-rata di atas 3 persen ini merupakan salah satu indikasi adanya masalah dalam komitmen organisasional karyawan. Ini berarti niat karyawan yang melibatkan diri dalam kegiatan perusahaan cenderung rendah, sehingga dapat dikatakan komitmen organisasional karyawan tergolong rendah. Hal tersebut terindikasi dari data absensi perusahaan yang menunjukkan sebagian besar karyawan yang tidak hadir tanpa pemberitahuan serta karyawan yang absen secara berturut-turut.

Hasil wawancara pendahuluan terhadap 5 orang karyawan dan HRD CV. Tirta Tamanbali mengenai komitmen organisasional, ditemukan adanya indikasi rendahnya komitmen organisasional karyawan. Hal ini ditunjukkan dari keluhan yang diutarakan oleh karyawan antara lain karyawan tidak memiliki keinginan untuk bekerja di perusahaan ini sepanjang karirnya, sehingga adanya indikasi karyawan akan meninggalkan perusahaan ini. Disamping itu, karyawan tidak merasa masalah yang terjadi di perusahaan menjadi masalah mereka, karyawan juga tidak takut dan tidak merasa dirugikan jika meninggalkan perusahaan ini. Jika karyawan keluar dari perusahaan ini maka karyawan merasa mampu mendapatkan pekerjaan dengan penghasilan yang lebih baik di luar perusahaan. Menurut hasil wawancara dengan HRD CV. Tirta Tamanbali, menyataan bahwa pada tahun 2018 terdapat karyawan yang didemosi. Hal ini terjadi karena karyawan tersebut telah mengabaikan kewajibannya, dengan kata lain komitmen organisasional karyawan tersebut rendah.

Rendahnya komitmen organisasional karyawan juga terindikasi dari keluhan yang diutarakan oleh karyawan antara lain karyawan merasa budaya organisasi yang kurang kuat di dalam perusahaan. Salah satunya adalah kurangnya dukungan dari rekan kerja serta kurangnya rasa saling memiliki yang kuat dalam perusahaan. Rendahnya komitmen organisasional juga terindikasi dari keadilan organisasional yang kurang adil di dalam perusahaan. Menurut hasil wawancara, karyawan merasa jumlah bonus yang didapatkan diakhir tahun tidak sama antara karyawan satu dan lainnya, sehingga karyawan merasa perusahaan kurang adil dalam menyikapi hal tersebut. Hasil wawancara juga menemukan indikasi rendahnya komitmen organisasional karyawan yang disebabkan oleh motivasi kerja karyawan yang kurang tinggi. Karyawan menyatakan bahwa karyawan tidak dapat bekerja dengan gigih dan bersungguh-sungguh jika lingkungan di tempat kerjanya kurang mendukung.

Penelitian sebelumnya mengatakan bahwa budaya organisasi sangat penting untuk kemajuan organisasi karena berdampak pada komitmen karyawan. Budaya organisasi harus dikembangkan agar dapat memberikan dukungan kepada organisasi dan membawa perbaikan terus menerus (Habib et al., 2014). Organisasi memiliki budaya dan kepribadian yang berbeda yang menunjukkan nilai-nilai mereka, cara menghadapi masalah, pengambilan keputusan, dan melakukan sesuatu (Wambui \& Gichanga, 2018). Menurut Andriani (2017) bahwa tanpa adanya budaya organisasi, seorang karyawan cenderung merasa segan untuk melaksanakan 
suatu tugas dengan baik apapun statusnya dalam organisasi tersebut, karena kurangnya kesepakatan komitmen yang tegas. Penelitian sebelumnya oleh ( \& Surya (2017) menyatakan bahwa semakin kuat budaya organisasi maka komitmen organisasional akan semakin meningkat.

Faktor lain yang dapat meningkatkan komitmen organisasional yaitu keadilan organisasional, pernyataan tersebut dinyatakan oleh Sethi et al. (2013). Organisasi dapat meningkatkan komitmen karyawannya dengan cara memastikan bahwa semua karyawan telah diberlakukan secara adil. Munculnya persepsi adil dalam pikiran karyawan dapat berdampak positif bagi perusahaan, di mana karyawan akan memiliki perasaan emosional yang positif pada pekerjaannya, sehingga akan meningkatkan komitmennya dalam bekerja. Karyawan yang merasa diberlakukan dengan adil dalam organisasi lebih berkomitmen dengan pekerjaan mereka dan karyawan yang merasa tidak diberlakukan adil akan cenderung untuk meninggalkan organisasi. Bazgir et al. (2018) menyatakan keberadaan keadilan organisasional di tempat kerja menunjukkan pentingnya organisasi bagi karyawan dan dalam situasi ini, karyawan akan berkomitmen pada organisasi.

Hal penting lain dalam mengelola sumber daya manusia di dalam organisasi adalah melalui motivasi kerja. Motivasi merupakan proses yang menjelaskan mengenai kekuatan, arah dan ketekunan seseorang dalam upaya untuk mencapai tujuan (Robbins \& Timothy, 2008:222). Motivasi kerja adalah elemen penting dalam menentukan produktivitas dan efisiensi karyawan. Ini dapat didefinisikan sebagai proses manajemen untuk mempengaruhi perilaku berdasarkan pada pengetahuan tentang apa yang membuat orang berpikir. Oleh karena itu, perlu motivasi yang kuat dan efektif di berbagai tingkatan untuk dapat dipahami untuk memuaskan karyawan dan membuat mereka berkomitmen untuk pekerjaan mereka (Salleh et al., 2016). Menurut Yudha \& Hasib (2014) motivasi kerja memiliki hubungan yang kuat terhadap komitmen organisasional. Semakin tinggi motivasi yang dirasakan karyawan untuk bekerja maka semakin karyawan merasa enggan untuk meninggalkan perusahaan.

Hasil penelitian yang dilakukan oleh Siswanto (2015) mendapatkan hasil bahwa budaya organisasi berpengaruh positif dan signifikan terhadap komitmen organisasional. Mitic et al. (2016) menyatakan budaya organisasi memiliki pengaruh positif dan signifikan terhadap komitmen organisasional. Jika manajer menginginkan komitmen karyawan yang lebih besar, mereka harus meningkatkan budaya organisasi perusahaannya agar semakin kuat. Penelitian yang dilakukan oleh Nimran et al. (2016) mendapatkan hasil bahwa budaya organisasi berpengaruh positif dan signifikan terhadap komitmen organisasional.

Usmany et al. (2016) dalam penelitiannya mendapatkan hasil bahwa budaya organisasi berpengaruh positif dan signifikan terhadap komitmen organisasional. Lanjar et al. (2017) dalam penelitiannya menyatakan bahwa budaya organisasi berpengaruh positif dan signifikan terhadap komitmen organisasional. Penelitian serupa yang dilakukan oleh Rahmi \& Mulyadi (2018) mendapatkan hasil bahwa budaya organisasi berpengaruh positif dan signifikan terhadap komitmen organisasional karyawan pada PT. PLN Banda Aceh. Data ini mendukung bahwa budaya organisasi yang semakin kuat akan menghasilkan komitmen organisasional karyawan yang semakin tinggi. 
$\mathrm{H}_{1}$ : Budaya organisasi berpengaruh positif dan signifikan terhadap komitmen organisasional.

Hasil penelitian yang dilakukan oleh Kristanto (2015) pada 38 karyawan di CV. Tanaya Fiberglass menemukan bahwa keadilan organisasional berpengaruh positif dan signifikan terhadap komitmen organisasional. Penelitian yang dilakukan oleh Nurmaladita \& Lucy (2015) mendapatkan bahwa keadilan organisasional berpengaruh positif dan signifikan terhadap komitmen organisasional. Dimana pengaruh positif berarti jika keadilan organisasi meningkat, maka komitmen organisasi akan meningkat dan sebaliknya. Cabral \& Suprapti (2017) menyatakan bahwa keadilan organisasional berpengaruh positif dan signifikan terhadap komitmen organisasional.

Penelitian yang dilakukan oleh Yuliani et al. (2016) mendapatkan hasil bahwa keadilan organisasional memiliki pengaruh positif dan signifikan terhadap komitmen organisasional. Cagliyan et al. (2017) dalam penelitiannya mendapatkan hasil bahwa keadilan organisasional berpengaruh positif dan signifikan terhadap komitmen organisasional. Penelitian yang serupa oleh Hutagalung dan Wibawa (2018) menyatakan bahwa keadilan organisasional berpengaruh positif dan signifikan terhadap komitmen organisasional karyawan pada PT. Bank Rakyat Indonesia Cabang Denpasar.

$\mathrm{H}_{2}$ : Keadilan organisasional berpengaruh positif dan signifikan terhadap komitmen organisasional.

Hasil penelitian yang dilakukan oleh Yudha \& Hasib (2014) menyatakan bahwa motivasi kerja berpengaruh positif dan signifikan terhadap komitmen organisasional atau dengan kata lain semakin tinggi motivasi kerja yang dimiliki karyawan dalam bekerja maka semakin meningkat komitmen organisasional karyawan tersebut. Arunkumar (2014) menyatakan bahwa motivasi kerja karyawan berpengaruh positif dan signifikan terhadap komitmen organisasional. Penelitian serupa yang dilakukan oleh Rahmayani et al. (2017) mendapatkan hasil bahwa terdapat pengaruh motivasi kerja yang positif dan signifikan terhadap komitmen organisasional. Nurlaely \& Riani (2016) dalam penelitiannya mendapatkan hasil bahwa motivasi kerja berpengaruh positif dan signifikan terhadap komitmen organisasional. Hasil penelitian yang dilakukan oleh Sousa (2017) menyatakan bahwa motivasi berpengaruh positif dan signifikan terhadap komitmen organisasional.

$\mathrm{H}_{3}$ : Motivasi kerja berpengaruh positif dan signifikan terhadap komitmen organisasional.

Teori pertukaran sosial (social exchange theory) yang semula dikembangkan oleh Thibaut dan Kelley pada tahun 1959, karyawan akan menukar upaya mereka dengan perjanjian penghargaan di masa depan (Korir \& Kipkebut, 2016). Teori pertukaran sosial mengemukakan bahwa orang yang mengevaluasi hubungannya dengan orang lain dengan mempertimbangkan konsekuensinya, khususnya terhadap ganjaran yang diperoleh dan upaya yang telah dilakukan, orang tersebut akan memutuskan untuk tetap tinggal dalam suatu hubungan.

Teori pertukaran sosial merupakan pandangan karyawan ketika mereka telah diperlakukan dengan baik oleh organisasi, mereka akan cenderung untuk bersikap dan berperilaku lebih positif terhadap organisasi (Fung et al., 2012). Seluruh 
manusia akan selalu berusaha untuk membalas budi terhadap siapapun yang telah memberikannya keuntungan. Teori pertukaran sosial menjelaskan bagaimana menjaga keseimbangan pertukaran sosial antara karyawan dan organisasi. Pertukaran dapat terjadi apabila dua belah pihak mampu memberikan sesuatu hal yang menguntungkan satu sama lain.

Komitmen organisasional merupakan suatu perasaan individu untuk tetap bertahan di suatu organisasi dan menuangkan seluruh kemampuannya untuk mencapai tujuan organisasi (Putra \& Indrawati, 2018). Dyantini \& Dewi (2016) menyatakan komitmen organisasional merupakan suatu keadaan seorang karyawan merasa nyaman atas pekerjaan dan tempat kerjanya, sehingga memiliki keinginan untuk tetap berada di dalam organisasi tersebut. Komitmen organisasional sebagai suatu psikologi yang dikarakteristikan dengan meyakini serta menerima tujuan yang dimiliki oleh organisasi, berusaha dengan maksimal demi tercapainya organisasi yang unggul dan mempunyai keinginan yang kuat untuk tetap menjadi anggota organisasi (Widyanto \& Kartika, 2013)

Suatu organisasi apapun bentuknya sangat memerlukan adanya komitmen yang tinggi dari seluruh anggotanya sehingga tujuan-tujuan organisasi dan individu dapat tercapai (Safitri et al., 2014). Komitmen organisasional dapat digambarkan sebagai kekuatan yang memikat individu untuk suatu tindakan yang relevan dengan tujuan dan sasaran organisasi yang memperkerjakan. Komitmen terhadap organisasi akan membuat karyawan setia pada organisasi dan bekerja dengan baik untuk kepentingan organisasi (Chamdan, 2013)

Budaya atau kultur yang terdapat dalam organisasi disebut sebagai budaya organisasi. Budaya organisasi merupakan suatu sistem makna bersama yang dibentuk oleh para anggota organisasi yang membedakan organisasi tersebut dengan organisasi lainnya (Robbins \& Timothy, 2008:222). Belias \& Koustelios (2014) mendefinisikan budaya organisasi merupakan pola asumsi dasar untuk mengatasi masalah eksternal maupun integrasi internal dan yang telah bekerja cukup baik untuk dianggap sah. Budaya organisasi yang kondusif akan mendorong karyawan untuk menunjukkan kinerja yang optimal. Budaya organisasi yang kuat akan berpengaruh pada perilaku anggota organisasi secara keseluruhan.

Budaya organisasi adalah serangkaian nilai, keyakinan, perilaku, kebiasaan, dan sikap membantu seorang anggota dalam memahami prinsip-prinsip yang dianut oleh organisasi tersebut (Ekobelawati, 2019). Budaya organisasi memiliki peran yang sangat strategis untuk mendorong dan meningkatkan efektivitas kinerja organisasi, khususnya kinerja karyawan baik dalam jangka pendek maupun jangka panjang. Peran budaya organisasi adalah sebagai alat untuk menentukan arah organisasi, mengarahkan apa yang boleh dan tidak boleh dilakukan, bagaimana mengalokasikan sumber daya organisasional dan juga sebagai alat untuk menghadapi masalah dan peluang dari lingkungan organisasi (Muis et al., 2018).

Keadilan organisasional merupakan persepsi seorang karyawan yang dirasakan terkait organisasi yang mampu memberikan perlakuan yang adil kepada karyawan (Suardani \& Supartha, 2018). Mada et al. (2017) mendefinisikan keadilan organisasional merupakan persepsi keadilan yang dirasakan karyawan dari proses yang diterapkan perusahaan dalam distribusi imbalan dan keputusan yang dibuat 
serta perlakuan terhadap karyawan dengan penuh martabat, perhatian, dan rasa hormat.

Keadilan organisasional adalah persepsi keseluruhan mengenai apa itu keadilan di tempat kerja (Robbins \& Timothy, 2008:222). Keadilan seharusnya dapat dirasakan semua pihak dalam organisasi tetapi semua itu tidak dapat terwujud dengan mudah, bahkan ada karyawan yang merasa diperlakukan tidak adil. Menurut Candika \& Chairoel (2018) ketidakadilan dapat dilatar belakangi banyak hal diantaranya, penawaran tenaga kerja yang jauh lebih tinggi dibanding permintaan karyawan yang berakibat pada lemahnya kekuatan daya tawar karyawan kepada perusahaan terhadap kebijakan output organisasional dan output kerja yang mereka terima. Sehingga kebijakan output organisasional dan promosi relatif rendah.

Motivasi adalah pemberian daya gerak yang menciptakan kegairahan kerja seseorang, agar mereka mau bekerja sama, bekerja efektif dan terintergrasi dengan segala daya dan upayanya untuk mencari kepuasan (Malayu, 2014:219). Menurut Dobre (2013) motivasi merupakan alat yang ampuh dalam memperkuat perilaku dan pemicu kecenderungan untuk melanjutkan sesuatu dengan kata lain, motivasi adalah dorongan internal untuk memenuhi kebutuhan dan keinginan yang tidak memuaskan mencapai untuk tujuan tertentu.

Motivasi kerja adalah seperangkat kekuatan energetik yang berasal dari dalam dan di luar diri seseorang untuk membangun perilaku yang terkait dengan pekerjaan. Karyawan yang termotivasi menyadari tujuan yang harus dicapai dan upaya mereka untuk mencapai target. Mereka juga merasa lebih sedikit tekanan, mencintai pekerjaan mereka dan memiliki kesehatan fisik dan mental yang lebih baik (Salleh et al., 2016). Karyawan yang memiliki motivasi kerja yang tinggi, mereka akan mengerti apa yang dikerjakan, bersemangat dalam bekerja, bekerja dengan senang hati tanpa ada tekanan dan mampu memberikan hasil yang terbaik. Pemberian dorongan berupa motivasi kerja dari atasan kepada bawahan yang dilakukan secara terus menerus akan menciptakan hubungan yang baik antara atasan dengan bawahan. Karyawan yang diberikan dorongan akan merasa diperhatikan, dihargai, dan merasa dilibatkan dalam kegiatan organisasi, kemudian akan tumbuh komitmen terhadap organisasi.

\section{METODE PENELITIAN}

Lokasi penelitian ini adalah di CV. Tirta Tamanbali yang beralamat di Br. Umanyar, Desa Tamanbali, Kabupaten Bangli. Perusahaan ini dipilih sebagai lokasi penelitian karena diduga terdapat masalah yang menyangkut rendahnya komitmen organisasional pada karyawan CV. Tirta Tamanbali. Obyek penelitian ini adalah budaya organisasi, keadilan organisasional, motivasi kerja dan komitmen organisasional karyawan di CV. Tirta Tamanbali.

Populasi dalam penelitian ini adalah karyawan yang ada di CV. Tirta Tamanbali dengan jumlah populasi 133 karyawan. Jumlah karyawan CV. Tirta Tamanbali dapat dilihat pada Tabel 2. Penelitian ini dalam menentukan metode penentuan sampel menggunakan teknik Probability Sampling yaitu Simple Random Sampling. Dikatakan Simple Random Sampling karena pengambilan anggota 
sampel dari populasi dilakukan secara acak tanpa memperhatikan strata yang ada dalam populasi itu (Sugiyono, 2019:129).

Menentukan jumlah sampel dari sebuah populasi, peneliti menggunakan rumus Slovin, yaitu:

$\mathrm{N}=\frac{N}{1+N e^{2}}$.

Keterangan:

$\mathrm{n} \quad=$ sampel

$\mathrm{N} \quad=$ populasi

e $\quad$ error

Jumlah populasi pada CV. Tirta Tamanbali berjumlah 133 karyawan, sehingga:

$\frac{133}{1+133(0.05)^{2}}=99,81$

Berdasarkan rumus slovin jumlah sampel yang didapat adalah 99,81 yang dibulatkan menjadi 100 responden. Distribusi populasi dan sampel dapat dilihat pada Tabel 2.

Tabel 2.

Populasi dan Sampel

\begin{tabular}{|c|c|c|c|}
\hline No & Divisi & Populasi & Sampel \\
\hline 1 & Produksi & 36 & 27 \\
\hline 2 & Quality Control & 5 & 4 \\
\hline 3 & Water Treatment & 13 & 10 \\
\hline 4 & Distribusi & 31 & 23 \\
\hline 5 & Administrasi & 4 & 3 \\
\hline 6 & Pemasaran & 3 & 2 \\
\hline 7 & Kasir & 3 & 2 \\
\hline 8 & Gudang & 8 & 6 \\
\hline 9 & Teknisi & 6 & 5 \\
\hline 10 & Satpam & 16 & 12 \\
\hline \multirow[t]{2}{*}{11} & Cleaning Service & 8 & 6 \\
\hline & Total & 133 & 100 \\
\hline
\end{tabular}

Sumber: Data diolah, 2019

Metode regresi linier berganda digunakan dalam penelitian ini untuk mengetahui pengaruh budaya organisasi, keadilan organisasional, dan motivasi kerja terhadap komitmen organisasional. Persamaannya sebagai berikut:

$Y=\beta_{1} X_{1}+\beta_{2} X_{2}+\beta_{3} X_{3}+\varepsilon$

Keterangan :

$\mathrm{Y}=$ Komitmen Organisasional

$\mathrm{X}_{1} \quad=$ Budaya Organisasi

$\mathrm{X}_{2} \quad=$ Keadilan Organisasional

$\mathrm{X}_{3} \quad=$ Motivasi Kerja

$\alpha=$ Konstanta

$\beta_{1} \quad=$ Koefisien regresi Budaya Organisasi

$\beta_{2} \quad=$ Koefisien regresi Keadilan Organisasional 


$$
\begin{array}{ll}
\beta_{3} & =\text { Koefisien regresi Motivasi Kerja } \\
\varepsilon & =\text { error }
\end{array}
$$

\section{HASIL DAN PEMBAHASAN}

Ringkasan mengenai karakteristik responden dapat dilihat dari Tabel 3.

Tabel 3.

\begin{tabular}{|c|c|c|c|}
\hline \multirow{2}{*}{ No. } & \multirow{2}{*}{ Jenis Kelamin } & \multicolumn{2}{|c|}{ Jumlah } \\
\hline & & Orang & Persentase \\
\hline 1 & Laki-laki & 55 & 55 \\
\hline \multirow[t]{2}{*}{2} & Perempuan & 45 & 45 \\
\hline & Jumlah & 100 & 100 \\
\hline No & Umur & \multicolumn{2}{|c|}{ Jumlah } \\
\hline & Unuा & Orang & Persentase \\
\hline 1 & $22-<29$ & 26 & 26 \\
\hline 2 & $29-<36$ & 46 & 46 \\
\hline 3 & $36-<43$ & 18 & 18 \\
\hline \multirow{2}{*}{4} & $43-\leq 50$ & 10 & 10 \\
\hline & Jumlah & 100 & 100 \\
\hline No & Tingkat Pendidikan & \multicolumn{2}{|c|}{ Jumlah } \\
\hline No & Iingkat Pendiakan & Orang & Persentase \\
\hline 1 & $\mathrm{SD}$ & 4 & 4 \\
\hline 2 & SMP & 18 & 18 \\
\hline 3 & SMA/SMK/Sederajat & 62 & 62 \\
\hline 4 & Diploma & 9 & 9 \\
\hline \multirow[t]{2}{*}{5} & Sarjana & 7 & 7 \\
\hline & Jumlah & 100 & 100 \\
\hline No & Jabatan & \multicolumn{2}{|c|}{ Jumlah } \\
\hline No & Jaoatan & Orang & Persentase \\
\hline 2 & Produksi & 27 & 27 \\
\hline 3 & Quality Control & 4 & 4 \\
\hline 4 & Water Treatment & 10 & 10 \\
\hline 5 & Distribusi & 23 & 23 \\
\hline 6 & Administrasi & 3 & 3 \\
\hline 7 & Pemasaran & 2 & 2 \\
\hline 8 & Kasir & 2 & 2 \\
\hline 9 & Gudang & 6 & 6 \\
\hline 10 & Teknisi & 5 & 5 \\
\hline 11 & Cleaning Service & 6 & 6 \\
\hline \multirow[t]{2}{*}{12} & Satpam & 12 & 12 \\
\hline & Jumlah & 100 & 100 \\
\hline No & Masa Kerja & \multicolumn{2}{|c|}{ Jumlah } \\
\hline 1 & $1-4$ & $\begin{array}{c}\text { Orang } \\
29\end{array}$ & $\begin{array}{c}\text { Persentase } \\
29\end{array}$ \\
\hline 2 & $5-8$ & 43 & 43 \\
\hline 3 & $9-12$ & 27 & 27 \\
\hline \multirow[t]{2}{*}{4} & $13-16$ & 1 & 1 \\
\hline & Jumlah & 100 & 100 \\
\hline
\end{tabular}

Karakteristik Responden Karyawan CV. Tirta Tamanbali

Sumber: Data diolah, 2019

Kriteria jenis kelamin responden berdasarkan Tabel 3. dapat dilihat bahwa responden berjenis kelamin laki-laki lebih banyak dibandingkan berjenis kelamin 
perempuan yaitu berjumlah 55 responden $(55 \%)$. Berdasarkan hasil wawancara dengan HRD CV. Tirta Tamanbali, jumlah responden karyawan laki-laki di CV. Tirta Tamanbali lebih banyak karena kebutuhan terhadap karyawan yang bekerja di lapangan, seperti pada bagian produksi serta distribusi yang mendistribusikan produk ke seluruh gerai yang berada di Bali.

Kriteria usia responden berdasarkan Tabel 3. dapat dilihat bahwa responden terbanyak adalah yang berusia 29 - < 36 tahun. Berdasarkan hasil wawancara dengan HRD CV. Tirta Tamanbali, hal ini dikarenakan CV. Tirta Tamanbali merekrut karyawan yang sebagian besar sudah memiliki pengalaman kerja dimana karyawan tersebut dominan berusia $29-<36$ tahun.

Kriteria tingkat pendidikan responden berdasarkan Tabel 3 dapat dilihat bahwa responden dengan tingkat pendidikan terbanyak adalah SMA/SMK/Sederajat yang berjumlah 62 responden (62\%). Berdasarkan hasil wawancara dengan HRD CV. Tirta Tamanbali, jumlah responden karyawan dengan lulusan SMA/SMK/Sederajat di CV. Tirta Tamanbali paling banyak dikarenakan CV. Tirta Tamanbali lebih banyak membutuhkan karyawan di bagian lapangan dibandingkan dengan di dalam kantor sehingga lulusan SMA/SMK/Sederajat sudah cukup untuk ditugaskan di lapangan selama karyawan mampu bekerja dengan sungguh-sungguh.

Kriteria jabatan responden berdasarkan Tabel 3. dapat dilihat bahwa responden pada bagian produksi berjumlah 27 responden (27\%). Berdasarkan hasil wawancara dengan HRD CV. Tirta Tamanbali, jumlah kriteria jabatan pada bagian produksi di CV. Tirta Tamanbali sebagai kriteria terbanyak dikarenakan CV. Tirta Tamanbali merupakan pabrik air dalam kemasan yang dimana bagian produksi merupakan bagian terpenting dalam kinerja perusahaan sehingga kegiatan tersebut harus berjalan dengan efektif, maka jumlah karyawan pada bagian produksi lebih banyak dari bagian lainnya.

Kriteria masa kerja responden berdasarkan Tabel 3. dapat dilihat bahwa responden dengan masa kerja terbanyak adalah 5 - 8 tahun yang berjumlah 43 responden $(43 \%)$. Berdasarkan hasil wawancara dengan HRD CV. Tirta Tamanbali, hal ini dikarenakan 1 - 4 tahun terakhir CV. Tirta Tamanbali hanya merekrut karyawan dengan kriteria tertentu seperti tingkat pendidikan terakhir yaitu diploma dan sarjana untuk diletakkan pada bagian kantor dan karyawan dengan masa kerja 9 tahun ke atas tergolong sedikit dikarenakan banyaknya karyawan yang keluar dari perusahaan.

Instrumen yang valid berarti alat ukur yang digunakan untuk mendapatkan data (mengukur) itu valid. Valid berarti instrumen tersebut dapat digunakan untuk mengukur apa yang seharusnya diukur. Uji validitas dilakukan dengan cara mengkorelasikan jumlah skor faktor dengan skor total. Bila korelasi tiap faktor tersebut positif dan besarnya $0,3 \mathrm{ke}$ atas maka faktor tersebut merupakan construct yang kuat. Rekapitulasi hasil uji validitas instrumen dapat dilihat pada Tabel 4. 
Tabel 4.

Rekapitulasi Hasil Uji Validitas Instrumen Penelitian

\begin{tabular}{|c|c|c|c|}
\hline Variabel & Indikator & Koefisien Korelasi & Keterangan \\
\hline & $\mathrm{Y} 1.1$ & 0,755 & Valid \\
\hline & Y1.2 & 0,688 & Valid \\
\hline & Y1.3 & 0,735 & Valid \\
\hline & Y1.4 & 0,883 & Valid \\
\hline & Y1.5 & 0,765 & Valid \\
\hline & Y1.6 & 0,584 & Valid \\
\hline & Y1.7 & 0,814 & Valid \\
\hline & Y1.8 & 0,836 & Valid \\
\hline & Y1.9 & 0,712 & Valid \\
\hline & Y1.10 & 0,686 & Valid \\
\hline Komitmen & Y1.11 & 0,828 & Valid \\
\hline \multirow[t]{17}{*}{ Organisasional (Y) } & Y1.12 & 0,682 & Valid \\
\hline & Y1.13 & 0,791 & Valid \\
\hline & Y1.14 & 0,789 & Valid \\
\hline & Y1.15 & 0,827 & Valid \\
\hline & Y1.16 & 0,779 & Valid \\
\hline & Y1.17 & 0,683 & Valid \\
\hline & Y1.18 & 0,662 & Valid \\
\hline & Y1.19 & 0,847 & Valid \\
\hline & Y1.20 & 0,719 & Valid \\
\hline & Y1.21 & 0,736 & Valid \\
\hline & Y1.22 & 0,841 & Valid \\
\hline & $\mathrm{X} 1.1$ & 0,769 & Valid \\
\hline & $\mathrm{X} 1.2$ & 0,809 & Valid \\
\hline & $\mathrm{X} 1.3$ & 0,733 & Valid \\
\hline & $\mathrm{X} 1.4$ & 0,806 & Valid \\
\hline & $\mathrm{X} 1.5$ & 0,809 & Valid \\
\hline & $\mathrm{X} 1.6$ & 0,792 & Valid \\
\hline \multirow[t]{9}{*}{ Budaya Organisasi $\left(\mathrm{X}_{1}\right)$} & $\mathrm{X} 1.7$ & 0,844 & Valid \\
\hline & $\mathrm{X} 1.8$ & 0,830 & Valid \\
\hline & $\mathrm{X} 1.9$ & 0,789 & Valid \\
\hline & $\mathrm{X} 1.10$ & 0,814 & Valid \\
\hline & $\mathrm{X} 1.11$ & 0,735 & Valid \\
\hline & $\mathrm{X} 1.12$ & 0,884 & Valid \\
\hline & $\mathrm{X} 1.13$ & 0,851 & Valid \\
\hline & $\mathrm{X} 2.1$ & 0,895 & Valid \\
\hline & $\mathrm{X} 2.2$ & 0,864 & Valid \\
\hline \multirow{6}{*}{$\begin{array}{l}\text { Keadilan Organisasional } \\
\qquad\left(\mathrm{X}_{2}\right)\end{array}$} & $\mathrm{X} 2.3$ & 0,822 & Valid \\
\hline & $\mathrm{X} 2.4$ & 0,814 & Valid \\
\hline & $\mathrm{X} 2.5$ & 0,809 & Valid \\
\hline & $\mathrm{X} 2.6$ & 0,890 & Valid \\
\hline & X3.1 & 0,716 & Valid \\
\hline & X3.2 & 0,795 & Valid \\
\hline \multirow{4}{*}{ Motivasi Kerja $\left(\mathrm{X}_{3}\right)$} & X3.3 & 0,861 & Valid \\
\hline & X3.4 & 0,850 & Valid \\
\hline & $\mathrm{X} 3.5$ & 0,847 & Valid \\
\hline & X3.6 & 0,849 & Valid \\
\hline
\end{tabular}

Sumber: Data diolah, 2019

Reliabilitas instrumen merupakan syarat untuk pengujian validitas instrumen. Oleh karena itu walaupun instrumen yang valid umumnya pasti reliabel, tetapi 
pengujian reliabilitas instrumen perlu dilakukan. Nilai suatu instrumen dapat dikatakan reliabel bila nilai Cronbach's Alpha $\geq 0,6$. Rekapitulasi uji reliabilitas instrumen dapat dilihat pada Tabel 5.

Tabel 5.

Rekapitulasi Uji Reliabilitas Instrumen Penelitian

\begin{tabular}{cccc}
\hline No & Variabel & Cronbach's Alpha & Keterangan \\
\hline 1 & Komitmen Organisasional (Y) & 0,964 & Reliabel \\
2 & Budaya Organisasi (X1) & 0,956 & Reliabel \\
3 & Keadilan Organisasional X2) & 0,917 & Reliabel \\
$\mathbf{4}$ & Motivasi Kerja (X3) & 0,902 & Reliabel \\
\hline
\end{tabular}

Sumber: Data diolah, 2019

Hasil uji reliabilitas instrumen yang disajikan pada Tabel 5 menunjukkan bahwa seluruh instrumen penelitian memiliki Cronbach's Alpha lebih dari 0,6. Hal ini dapat dikatakan bahwa seluruh instrumen penelitian adalah reliabel sehingga dapat digunakan untuk penelitian.

Uji normalitas bertujuan untuk menguji apakah dalam residual dalam model regresi yang dibuat apakah berdistribusi normal atau tidak. Uji normalitas pada penelitian ini menggunakan uji Komogorov-Sminarnov yaitu jika Sig (2-tailed) lebih besar dari 0,05 maka $\mathrm{H}_{0}$ diterima, selanjutnya disimpulkan bahwa residual yang dianalisis berdistribusi normal. Sebaliknya jika Sig (2-tailed) lebih kecil dari 0,05 berarti bahwa data yang dianalisis tidak berdistribusi normal. Hasil uji normalitas dapat dilihat pada Tabel 6.

Tabel 6.

Hasil Uji Normalitas

\begin{tabular}{lc}
\hline & Unstandardized Residual \\
\hline $\mathrm{N}$ & 100 \\
Asymp. Sig. (2-tailed) & 0,287 \\
Kolmogorov-Smirnov & 0,985 \\
\hline
\end{tabular}

Sumber: Data diolah, 2019

Hasil uji normalitas Komogorov-Sminarnov pada Tabel 6 menunjukkan bahwa Asymp. Sig (2-tailed) sebesar 0,287 > 0,05 (level of significant), sehingga dapat disimpulkan bahwa persamaan regresi tersebut berdistribusi normal.

Uji multikoleniaritas bertujuan untuk mengetahui apakah pada model regresi ditemukan adanya korelasi antara variabel bebas. Mendeteksi ada atau tidaknya korelasi antar sesama variabel bebas dapat dilihat dari nilai tolerance dan Variance Inflation Factor (VIF). Jika nilai tolerance lebih dari 10 persen atau VIF kurang dari 10, maka dikatakan tidak ada multikolonieritas. Hasil uji mulitkoleniaritas dapat dilihat pada Tabel 7.

Hasil uji multikoleniaritas pada Tabel 7. menunjukkan bahwa nilai Tolerance masing-masing variabel memiliki nilai lebih besar dari 0,1 dan nilai VIF kurang dari 10 sehingga dapat disimpulkan bahwa tidak terjadi hubungan multikoleniaritas antar variabel bebas dalam penelitian ini. 
Tabel 7.

Hasil Uji Multikolinearitas

\begin{tabular}{ccc}
\hline Variabel & Tolerance & VIF \\
\hline Budaya Organisasi & 0,573 & 1,744 \\
Keadilan Organisasional & 0,611 & 1,636 \\
Motivasi Kerja & 0,555 & 1,801 \\
\hline
\end{tabular}

Sumber: Data diolah, 2019

Uji heteroskedastisitas bertujuan untuk menguji apakah dalam model regresi terjadi ketidaksamaan varians dari residual satu pengamatan ke pengamatan yang lain. Mendeteksi ada atau tidaknya heteroskedastisitas dilakukan dengan melakukan uji Glejser, apabila probabilitas signifikansinya di atas tingkat kepercayaan 5\% maka dapat disimpulkan model regresi tidak mengandung heteroskedastisitas. Hasil uji heteroskedastisitas dapat dilihat pada Tabel 8.

Tabel 8.

Hasil Uji Heteroskedastisitas

\begin{tabular}{|c|c|c|c|c|c|}
\hline \multirow[b]{2}{*}{ Model } & \multicolumn{2}{|c|}{$\begin{array}{c}\text { Unstandardized } \\
\text { Coefficients }\end{array}$} & \multirow{2}{*}{$\begin{array}{c}\text { Standardized } \\
\text { Coefficients }\end{array}$} & \multirow[b]{2}{*}{ t } & \multirow[b]{2}{*}{ Sig. } \\
\hline & B & Std. Error & & & \\
\hline (Constant) & $-5,659$ & 3,309 & & $-1,711$ & 0,090 \\
\hline Budaya Organisasi & 0,128 & 0,075 & 0,221 & 1,722 & 0,088 \\
\hline $\begin{array}{c}\text { Keadilan } \\
\text { Organisasional }\end{array}$ & $-0,050$ & 0,136 & $-0,046$ & $-0,307$ & 0,712 \\
\hline Motivasi Kerja & 0,162 & 0,144 & 0,147 & 1,126 & 0,263 \\
\hline
\end{tabular}

Sumber: Data diolah, 2019

Hasil pengujian heteroskedastisitas pada Tabel 8. menunjukkan hasil signifikansi masing-masing variabel bebas lebih besar dari 0,05 sehingga dapat disimpulkan bahwa model regresi dalam penelitian ini bebas dari heteroskedastisitas.

Analisis regresi linear berganda digunakan oleh peneliti, bila peneliti ingin memprediksi bagaimana pengaruh dua atau lebih variabel bebas terhadap satu variabel terikat. Metode regresi linear berganda digunakan dalam penelitian ini untuk mengetahui pengaruh budaya organisasi, keadilan organisasional, dan motivasi kerja terhadap komitmen organisasional. Hasil analisis regresi linear berganda dapat dilihat pada Tabel 9.

Tabel 9.

Hasil Regresi Linear Berganda

\begin{tabular}{cccccc}
\hline & \multicolumn{7}{c}{$\begin{array}{c}\text { Unstandardized } \\
\text { Coefficients }\end{array}$} & $\begin{array}{c}\text { Standardized } \\
\text { Coefficients } \\
\text { Model }\end{array}$ & B & Std. Error & Beta & T & Sig. \\
\hline Budaya Organisasi & 0,613 & 0,120 & 0,403 & 5,121 & 0,000 \\
Keadilan & 0,466 & 0,218 & 0,163 & 2,142 & 0,035 \\
Organisasional & 1,097 & 0,231 & 0,379 & 4,745 & 0,000 \\
Motivasi Kerja & 0,659 & & & & \\
R Square & $.000^{\mathrm{a}}$ & & & & \\
Sig. F & 61,955 & & & &
\end{tabular}

Sumber: Data diolah, 2019 
Adapun persamaan regresi linear berganda menurut Tabel 9 adalah sebagai berikut:

$\mathrm{Y}=0,403 \mathrm{X}_{1}+0,163 \mathrm{X}_{2}+0,379 \mathrm{X}_{3}$

Uji F digunakan untuk menguji signifikansi secara serempak seluruh variabel bebas terhadap variabel terikat. Hasil perhitungan uji $\mathrm{F}$ jika menunjukkan angka yang jauh lebih kecil dari level of significant 0,05 yang biasa digunakan dalam penelitian ekonomi, maka secara serempak variabel bebas berpengaruh serempak terhadap variabel terikat. Hasil uji F dalam penelitian ini ditunjukkan dalam Tabel 9.

Berdasarkan hasil uji pada Tabel 9 menunjukkan nilai sig sebesar $0,000^{\mathrm{a}}$ yang lebih kecil dari $0,05\left(0,000^{\mathrm{a}}<0,05\right)$ yang berarti variabel bebas yaitu budaya organisasi $\left(\mathrm{X}_{1}\right)$, keadilan organisasional $\left(\mathrm{X}_{2}\right)$, motivasi kerja $\left(\mathrm{X}_{3}\right)$ berpengaruh signifikan secara serempak atau bersama-sama terhadap variabel terikat yaitu komitmen organisasional (Y), sehingga dapat disimpulkan penelitian ini memenuhi uji kelayakan model atau model penelitian ini dinyatakan layak digunakan sebagai model regresi.

Koefisien determinasi merupakan ukuran kesesuaian (goodness of fit) dari persamaan regresi, yaitu variasi dari variabel terikat yang mampu dijelaskan oleh variabel bebas. Berdasarkan hasil uji pada Tabel 9 nilai $R$ Square sebesar 0,659 sehingga dapat dihitung persentase kontribusi budaya organisasi, keadilan organisasional, dan motivasi kerja terhadap komitmen organisasional sebesar 0,659 $\times 100$ persen $=65,9 \%$ persen dan sisanya 34,1 persen dipengaruhi oleh variabel lain diluar penelitian.

Berdasarkan hasil regresi linier berganda pada Tabel 9 diketahui bahwa nilai koefisien beta variabel budaya organisasi bernilai positif yakni 0,403 dengan nilai sig sebesar 0,000. Nilai Sig 0,000 $<0,05$ mengindikasikan bahwa $\mathrm{H}_{1}$ diterima. Dengan kata lain budaya organisasi berpengaruh positif signifikan terhadap komitmen organisasional.

Berdasarkan hasil regresi linier berganda pada Tabel 9 diketahui bahwa nilai koefisien beta variabel keadilan organisasional bernilai positif yakni 0,163 dengan nilai sig sebesar 0,035. Nilai Sig 0,035 <0,05 mengindikasikan bahwa $\mathrm{H}_{1}$ diterima. Dengan kata lain keadilan organisasional berpengaruh positif signifikan terhadap komitmen organisasional.

Berdasarkan hasil regresi linier berganda pada Tabel 9 diketahui bahwa nilai koefisien beta variabel motivasi kerja bernilai positif yakni 0,379 dengan nilai sig sebesar 0,000. Nilai Sig. 0,000 <0,05 mengindikasikan bahwa $\mathrm{H}_{1}$ diterima. Dengan kata lain motivasi kerja berpengaruh positif signifikan terhadap komitmen organisasional.

Hasil analisis menunjukkan bahwa budaya organisasi berpengaruh positif dan signifikan terhadap komitmen organisasional. Hal ini memiliki arti bahwa semakin kuat budaya organisasi di dalam perusahaan, maka semakin tinggi komitmen organisasional karyawan. Pernyataan tersebut merujuk pada hasil jawaban responden mengenai budaya organisasi dalam kuesioner, yang menyatakan bahwa perusahaan sudah memiliki kebijakan yang jelas bagi karyawan. Hal tersebut 
mengindikasikan bahwa kebijakan dalam perusahaan yang dapat diterima dengan baik oleh karyawan, dapat meningkatkan kesetiaan karyawan terhadap perusahaan sehingga karyawan merasa tidak akan mendapatkan manfaat yang sama di perusahaan lain jika meninggalkan perusahaan ini.

Penelitian ini memperkuat hasil penelitian sebelumnya yang dilakukan oleh Siswanto (2015) yang menyatakan bahwa budaya organisasi memiliki pengaruh yang positif dan signifikan terhadap komitmen organisasional Guru di Sekolah Nusa Alam. Hasil penelitian yang dilakukan oleh Mitic et al. (2016) yang mendapatkan hasil bahwa secara keseluruhan, budaya organisasi dengan sangat pasti memiliki pengaruh yang positif dan signifikan terhadap komitmen organisasional. Jika manajer menginginkan komitmen karyawan yang lebih tinggi, maka mereka harus meningkatkan budaya organisasi perusahaannya agar semakin kuat. Nimran et al. (2016) menyatakan bahwa budaya organisasi berpengaruh positif dan signifikan terhadap komitmen organisasional, dengan kata lain budaya organisasi yang semakin kuat akan menghasilkan komitmen organisasional yang semakin tinggi.

Usmany et al. (2016) dalam penelitiannya mendapatkan hasil bahwa budaya organisasi berpengaruh positif dan signifikan terhadap komitmen organisasional. Lanjar et al. (2017) dalam penelitiannya menyatakan bahwa budaya organisasi berpengaruh positif dan signifikan terhadap komitmen organisasional. Penelitian serupa yang dilakukan oleh Rahmi \& Mulyadi (2018) mendapatkan hasil bahwa budaya organisasi berpengaruh positif dan signifikan terhadap komitmen organisasional karyawan pada PT. PLN Banda Aceh. Data ini mendukung bahwa budaya organisasi yang semakin kuat akan menghasilkan komitmen organisasional karyawan yang semakin tinggi.

Hasil analisis menujukkan bahwa keadilan organisasional berpengaruh positif dan signifikan terhadap komitmen organisasional. Hal ini memiliki arti bahwa semakin tinggi keadilan organisasional yang dirasakan oleh karyawan, maka semakin tinggi komitmen organisasional karyawan. Pernyataan tersebut merujuk pada hasil jawaban responden mengenai keadilan organisasional dalam kuesioner, yang menyatakan perusahaan ini sudah menunjukkan kepedulian terhadap karyawan. Kepedulian yang dirasakan oleh karyawan dapat mempengaruhi komitmen organisasional mereka. Hal tersebut dikarenakan kepedulian yang dirasakan oleh karyawan, dapat menjadikan mereka merasa berbahagia jika menghabiskan sisa karirnya di perusahaan ini.

Penelitian terdahulu yang dilakukan oleh Kristanto (2015) pada karyawan CV. Tanaya Fiberglass mendapatkan hasil bahwa keadilan organisasional berpengaruh positif dan signifikan terhadap komitmen organisasional. Hasil penelitian serupa yang dilakukan oleh Nurmaladita \& Lucy (2015) menyatakan keadilan organisasional berpengaruh positif dan signifikan terhadap komitmen organisasional. Dimana pengaruh positifnya berarti jika keadilan organisasional meningkat, maka komitmen organisasional akan meningkat dan sebaliknya. Yuliani et al. (2016) dalam penelitiannya, mendapatkan hasil bahwa keadilan organisasional berpengaruh positif dan signifikan terhadap komitmen organisasional. Karyawan yang diperlakukan secara adil, memiliki keinginan yang sedikit untuk meninggalkan perusahaan tempat mereka bekerja. 
Penelitian yang dilakukan oleh Cabral \& Suprapti (2017) serta Hutagalung \& Wibawa (2018) mendapatkan hasil yang sama yaitu keadilan organisasional berpengaruh positif dan signifikan terhadap komitmen organisasional. Penelitian serupa yang dilakukan oleh Cagliyan et al. (2017) mendapatkan hasil bahwa keadilan organisasional berpengaruh positif dan signifikan terhadap komitmen organisasional, yang dimana keadilan organisasional memiliki peran penting dalam proses meningkatkan komitmen karyawan di perusahaan.

Hasil analisis menunjukkan bahwa motivasi kerja berpengaruh positif dan signifikan terhadap komitmen organisasional. Hal ini memiliki arti bahwa semakin tinggi motivasi kerja yang dirasakan oleh karyawan CV. Tirta Tamanbali, maka semakin tinggi komitmen organisasional karyawan. Pernyataan tersebut merujuk pada hasil penelitian mengenai motivasi kerja di dalam kuesioner, yang menyatakan bahwa karyawan selalu ingin bekerja lebih baik lagi dari hari sebelumnya. Hal tersebut dapat meningkatkan komitmen organisasional karyawan dikarenakan memiliki arti ketika karyawan memiliki motivasi untuk bekerja lebih baik lagi dari hari sebelumnya, maka karyawan memiliki ikatan secara emosional terhadap perusahaan. Sehingga sulit bagi karyawan untuk meninggalkan perusahaan.

Penelitian ini memperkuat penelitian terdahulu yang dilakukan oleh Yudha \& Hasib (2014) yang mendapatkan hasil bahwa motivasi kerja berpengaruh positif dan signifikan terhadap komitmen organisasional. Hasil penelitian serupa yang dilakukan oleh Arunkumar (2014) menyatakan bahwa motivasi kerja merupakan faktor pendorong yang penting untuk meningkatkan komitmen organisasional karyawan, yang nantinya akan membantu manajer SDM untuk mempertahankan karyawan yang kompeten. Rahmayani et al. (2017) dalam penelitiannya, mendapatkan hasil bahwa motivasi kerja berpengaruh positif dan signifikan terhadap komitmen organisasional Guru SMP Negeri di Kecamatan Silih Nara Kabupaten Aceh Tengah.

Hasi penelitian yang dilakukan oleh Sousa (2017) serta Nurlaely \& Riani (2016) menyatakan bahwa jika motivasi kerja meningkat, maka komitmen organisasional karyawan juga akan meningkat dan sebaliknya. Hal ini berarti bahwa motivasi kerja memiliki peran penting dalam meningkatkan komitmen organisasional karyawan.

Penelitian ini menggunakan Teori Pertukaran Sosial atau Social Exchange Theory sebagai acuan. Teori ini menyatakan bahwa ketika karyawan diperlakukan dengan baik oleh organisasi, maka mereka akan cenderung untuk bersikap dan berperilaku lebih positif terhadap organisasi. Teori pertukaran sosial menjelaskan bagaimana menjaga keseimbangan pertukaran sosial antara karyawan dan organisasi. Pertukaran dapat terjadi apabila dua belah pihak mampu memberikan sesuatu hal yang menguntungkan satu sama lain. Teori ini terdukung dalam penelitian ini karena ketiga hipotesis penelitian dapat diterima. Karyawan akan memiliki komitmen organisasional yang tinggi apabila memiliki budaya organisasi yang kuat, keadilan organisasional yang adil, dan motivasi kerja yang tinggi.

Hasil dari penelitian ini memberikan sebuah implikasi teoritis mengenai bagaimana pengaruh budaya organisasi, keadilan organisasional, dan motivasi kerja terhadap komitmen organisasional. Hasil yang diperoleh dari penelitian ini menunjukkan bahwa karyawan CV. Tirta Tamanbali merasa bahwa budaya 
organisasi yang kuat dapat mingkatkan komitmen organisasional. Hal ini menunjukkan CV. Tirta Tamanbali memiliki kebijakan yang jelas terhadap seluruh karyawannya sehingga karyawan merasa budaya organisasi pada perusahaan mampu meningkatkan komitmen organisasional karyawan.

Keadilan organisasional juga diperlukan dalam meningkatkan komitmen organisasional karyawan. Hal ini dikarenakan karyawan yang merasakan kepedulian serta keadilan dari pihak perusahaan, maka kesetiaannya terhadap perusahaan semakin meningkat dengan kata lain komitmen organisasional karyawan semakin tinggi. Motivasi kerja yang dirasakan karyawan CV. Tirta Tamanbali juga dapat meningkatkan komitmen organisasional karyawan. Hal ini menunjukkan bahwa karyawan CV. Tirta Tamanbali merasa kewajiban untuk selalu meningkatkan kinerjanya merupakan tingkat usaha yang dapat memotivasi karyawan untuk selalu bekerja lebih baik lagi, sehingga dengan meningkatnya motivasi kerja karyawan maka meningkat pula komitmen organisasional karyawan. Hasil penelitian ini menemukan bahwa budaya organisasi, keadilan organisasional, dan motivasi kerja berpengaruh terhadap komitmen organisasional karyawan sehingga penelitian ini memberikan ide dan perspektif baru untuk peneliti lebih lanjut.

Penelitian ini diharapkan dapat memberikan kontribusi yang positif bagi pihak CV. Tirta Tamanbali untuk meningkatkan komitmen organisasional karyawan dengan mempertahankan budaya organisasi yang kuat, keadilan organisasional yang tinggi, dan meningkatkan motivasi kerja karyawan. Hal tersebut dapat dilakukan dengan mempertahankan kebijakan yang jelas di dalam perusahaan, mempertahankan rasa kepedulian yang diberikan oleh perusahaan kepada karyawan, serta dorongan-dorongan yang diberikan kepada karyawan sehingga mereka ingin bekerja lebih baik lagi dari hari sebelumnya.

\section{SIMPULAN}

Budaya organisasi berpengaruh positif dan signifikan terhadap komitmen organisasional karyawan di CV. Tirta Tamanbali. Hal ini menunjukkan bahwa semakin kuat budaya organisasi di dalam perusahaan maka komitmen organisasional karyawan juga semakin meningkat. Keadilan organisasional berpengaruh positif dan signifikan terhadap terhadap komitmen organisasional karyawan di CV. Tirta Tamanbali. Hal ini menunjukkan bahwa semakin tinggi keadilan organisasional yang diberikan perusahaan maka komitmen organisasional karyawan juga semakin meningkat. Motivasi kerja berpengaruh positif dan signifikan terhadap komitmen organisasional karyawan di CV. Tirta Tamanbali. Hal ini menunjukkan bahwa semakin tinggi motivasi kerja yang dimiliki karyawan maka komitmen organisasional karyawan juga semakin meningkat.

Tanggapan karyawan CV. Tirta Tamanbali pada variabel komitmen organisasional memperlihatkan indikator terendah yaitu komitmen bersinambung. Hal ini memiliki arti persepsi karyawan atas risiko jika meninggalkan perusahaan ini tergolong rendah. Pernyataan dengan nilai rata-rata terendah adalah saya merasa hidup saya akan terganggu jika meninggalkan perusahaan ini. Pernyataan tersebut menunjukkan bahwa karyawan tidak merasa hidupnya akan terganggu jika 
meninggalkan perusahaan ini. Saran bagi pihak CV. Tirta Tamanbali agar dapat memperhatikan produktivitas karyawan sehingga karyawan tidak merasa jenuh dalam bekerja dan akan tetap merasa nyaman bekerja di perusahaan ini.

Tanggapan karyawan CV. Tirta Tamanbali pada variabel budaya organisasi memperlihatkan indikator terendah adalah supportiveness. Hal ini berarti bahwa dukungan yang dirasakan karyawan masih tergolong rendah. Pernyataan dengan nilai rata-rata terendah pada indikator supportiveness yaitu saya menerima dukungan dari rekan kerja namun indikator tersebut masuk dalam kategori kuat. Saran bagi pihak CV. Tirta Tamanbali mengenai dukungan kerja yang dirasakan oleh karyawan agar karyawan CV. Tirta Tamanbali lebih menunjukkan rasa kepedulian terhadap sesame karyawan agar terciptanya keadaan saling mendukung antar karyawan.

Tanggapan karyawan CV. Tirta Tamanbali pada variabel keadilan organisasional memperlihatkan indikator terendah adalah keadilan distributif. Hal ini berarti bahwa persepsi keadilan yang dirasakan sebagian besar karyawan mengenai jumlah dan penghargaan yang diterima karyawan masih tergolong rendah. Pernyataan pada indikator keadilan distributif dengan nilai rata-rata terendah yaitu saya mendapatkan jumlah bonus yang sama dengan rekan kerja diakhir tahun namun indikator tersebut masuk dalam kategori adil. Saran bagi pihak CV. Tirta Tamanbali mengenai bonus diakhir tahun, agar dapat menyamaratakan bonus yang diberikan kepada karyawan sehingga karyawan tidak merasakan ketimpangan antar karyawan dalam menerima bonus akhir tahun dan lebih merasakan keadilan yang diberikan oleh perusahaan.

Tanggapan karyawan CV. Tirta Tamanbali pada variabel motivasi kerja memperlihatkan indikator terendah adalah arah perilaku. Hal ini berarti bahwa perilaku yang dipilih karyawan dalam bekerja masih menunjukkan sikap motivasi yang rendah. Pernyataan dengan nilai rata-rata terendah dari indikator tersebut yaitu saya selalu mematuhi peraturan perusahaan namun indikator tersebut masuk dalam kategori tinggi. Saran bagi pihak CV. Tirta Tamanbali yaitu agar memberikan arahan kepada karyawan mengenai bagaimana pentingnya untuk mematuhi peraturan perusahaan dan lebih memperhatikan sanksi-sanksi yang akan diberikan kepada karyawan yang melanggar peraturan yang telah ditetapkan.

\section{REFERENSI}

Andriani, L. (2017). Pengaruh Budaya Organisasi dan Kepemimpinan Terhadap Kinerja Karyawan Pada Dinas Pertanian Tanaman Pangan Provinsi Jambi. Jurnal Ilmiah Ekonomi Dan Bisnis, 8(2), 60-63.

Ardana, I. K., Mujiati, N. W., \& Utama, I. W. M. (2012). Manajemen Sumber Daya Manusia. Yogyakarta: Graha Ilmu.

Arunkumar, S. (2014). An Empirical Study: Relationship between Employee Motivation, Satisfaction and Organizational Commitment. International Journal of Management and Business Research, 4(2), 81-93. 
Bazgir, A., Vahdati, H., \& Nejad, S. H. M. (2018). A Study on The Effect of Organizational Justice and Commitment on the Organizational Citizenship Behavior. International Journal of Administrative Science \& Organization, 25(1), 9-15.

Belias, D., \& Koustelios, A. (2014). Organizational Culture and Job Satisfaction: A Review In University Of Thessaly, Karyes, 42100, Trikala, Greece. International Review of Management and Marketing, 4(2), 132-149.

Cabral, J. S., \& Suprapti, N. W. S. (2017). Pengaruh Keadilan Organisasional Terhadap Komitmen Organisasional yang Dimediasi Kepuasan Kerja Karyawan di Chilfund Timor Leste. E-Jurnal Ekonomi Dan Bisnis Unud, 6(7), 2889-2916.

Cagliyan, V., Attar, M., \& Derra, M. E. N. (2017). The Relationship Between Organizational Justice Perception and Organizational Commitment: A Study On Doğuş Otomotiv Authorized Dealers In Konya. The Journal of Faculty Of Economics and Administrative Sciences, 22(2), 599-612.

Candika, J., \& Chairoel, L. (2018). Pengaruh Keadilan Organisasional Terhadap Komitmen Organisasional Melalui Variabel Intervening Kepuasan Kerja Pada Karyawan PT. Lembah Karet Padang. Jurnal Benefita, 4(2), 248-262.

Chamdan, P. (2013). Influence Analysis of Organizational Culture Organizational Commitment Job and Satisfaction Organizational Citizenship Behavior (OCB) Toward Improved Organizational Performance. International Journal of Business, Humanities and Technology, 3(5), 86-100.

Dewi, I. G. A. K. R., \& Surya, I. B. K. (2017). Pengaruh Budaya Organisasi Terhadap Komitmen Organisasional dan Organizational Silence Pada PT. PLN rayon Denpasar. E-Jurnal Manajemen Unud, 6(1), 289-316.

Diputri, N. P. I. P., \& Rahyuda, A. G. (2016). Pengaruh Keadilan Organisasional, Budaya Organisasi, Pemberdayaan Karyawan Terhadap Komitmen Organisasi Pada LPD Desa Adat Kerobokan. E-Journal Manajemen Unud, 5(3), 1457-1485.

Dobre, O. I. (2013). Employee Motivation and Organizational Performance. Review of Apllied Socio-Economic Research, 5(1), 53-60.

Dyantini, N. N. A., \& Dewi, I. G. A. M. (2016). Pengaruh Komitmen Organisasional dan Penilaian KInerja Terhadap Turnover Intention. E-Jurnal Manajemen Unud, 5(11), 6851-6878.

Ekobelawati, F. (2019). Pengaruh Budaya Organisasi dan Kepuasan Kerja Terhadap Komitmen Organisasional Karyawan. Jurnal Ekonomi STIEP, 4(1), 
$40-44$.

Fung, N. S., Ahmad, A., \& Omar, Z. (2012). Work-Family Enrichment: It's Mediating Role in the Relationships between Dispositional Factors and Job Satisfaction. International Journal of Academic Research in Business and Social Sciences, 2(11), 73-88.

Habib, S., Aslam, S., Hussain, A., Yasmeen, S., \& Ibrahim, M. (2014). The Impact of Organizational Culture on Job Satisfaction, Employees Commitment, and Turnover Intention. Advances in Economics and Business., 2(6), 215-222.

Hutagalung, I. D. N., \& Wibawa, I. M. A. (2018). Pengaruh Keadilan Organisasional Terhadap Komitmen Organsiasional dan Turnover Intention Karyawan Pada PT. Bank Rakyat Indonesia. E-Jurnal Manajemen Unud, 7(1), 221-250.

Korir, I., \& Kipkebut, D. (2016). The Effect of Reward Management on Employes Commitment in the Universities in Nakuru Caunty-Kenya. Journal of Human Reource Management, 4(4), 37-48.

Kristanto, H. (2015). Keadilan Organisasional, Komitmen Organisasional, dan Kinerja Karyawan. Jurnal Manajemen Dan Kewirausahaan, 1(17), 86-98.

Lanjar, F. A., Hamid, D., \& Mukzam, M. D. (2017). Pengaruh Budaya Organisasi Terhadap Komitmen Organisasional dan Kinerja Karyawan (Studi Karyawan Pada Pabrik Gula Kremboong). Jurnal Administrasi Bisnis, 43(1), 10-18.

Luthans, F. (2006). Perilaku Organisasi. Yogyakarta: ANDI.

Mada, I. G. N. W., Sintaasih, D. K., \& Subudi, M. (2017). Pengaruh Keadilan Organisasional Terhadap Motivasi dan Kinerja Karyawan. Forum Manajemen, 15(2), 1-18.

Malayu, S. P. H. (2014). Manajemen Sumber Daya Manusia. Jakarta: Bumi Akasara.

Mitic, S., Vukonjanski, J., Terek, E., Gligorovic, B., \& Zoric, K. (2016). Organizational Culture and Organizational Commitment: Serbian Case. Journal of Engineering Management and Competitiveness, 6(1), 21-27.

Muis, M. R., Jufrizen, J., \& Fahmi, M. (2018). Pengaruh Budaya Organisasi dan Komitmen Organisasi Terhadap Kinerja Karyawan. Jurnal Ekonomi Dan Ekonomi Syariah, 1(1), 9-25.

Nimran, U., Taher, A., \& Steven, S. X. T. (2016). Pengaruh Budaya Organisasi Terhadap Kepuasan Kerja, Komitmen Organisasional dan Intention to Leave 
(Studi pada Karyawan PT. Bitung Mina Utama). Jurnal Bisnis Dan Manajemen, 3(1), 94-108.

Nurlaely, M., \& Riani, A. L. (2016). Pengaruh Disiplin Kerja, Motivasi Kerja, Kepuasan Kerja dan Kompetensi Terhadap Komitmen Organisasional. Jurnal Ekonomi Manajemen Sumber Daya, 18(1), 10-19.

Nurmaladita, \& Lucy, W. (2015). Pengaruh Keadilan Organisasional Terhadap Komitmen Organisasional Melalui Kepuasan Kerja Pada Karyawan BANK BNI Kantor Cabang Utama Margonda Depok Jawa Barat. Seminar Nasional Cendekiawan, 2(2), 746-754.

Putra, M., \& Indrawati, D. (2018). Pengaruh Keadilan Organisasi Terhadap Kepuasan Kerja dan Komitmen Organisasional di Hotel Rama Phala Ubud. E-Jurnal Manajemen Unud, 7(4), 2010-2040.

Rahman, A., Shahzad, N., Mustafa, K., Khan, M. F., \& Qurashi, F. (2015). Effects of Organizational Justice on Organizational Commitment. International Journal of Economics and Financial, 6(3), 188-196.

Rahmayani, Milfayetty, S., \& Dewi., R. (2017). Pengaruh Iklim Organisasi, Motivasi Kerja dan Kepuasan Kerja Terhadap Komitmen Organisasional Guru SMP Negeri di Kecamatan Silih Nara Kabupaten Aceh Tengah. Jurnal Manajemen Pendidikan, 9(2), 48-60.

Rahmi, A., \& Mulyadi. (2018). Pengaruh Keterlibatan Karyawan, Budaya Organisasi, dan Kepemimpinan Transformasional Terhadap Komitmen Organisasional Karyawan pada PT. PLN Banda Aceh. Jurnal Ilman, 6(1), 6876.

Robbins, S. P., \& Timothy, A. J. (2008). Perilaku Organisasi. Jakarta: Salemba Empat.

Safitri, I. P. W., Rahardjo, K., \& Djudi, M. (2014). Analisis Perbedaan Komitmen Organisasi Berdasarkan Status Karyawan (Studi Pada Karyawan PT. Kobexindo Tractors Tbk. Representative Office Bengkulu). Jurnal Administrasi Bisnis, 10(1), 215-239.

Salleh, S. M., Zahari, A. S. M., Said, N. S. M., \& Ali, S. R. O. (2016). The Influence of Work Motivation on Organizational Commitment in the Workplace. Jorunal of Applied Environmental and Biological Sciences, 6(5), 139-143.

Sethi, M., Hina., I., \& Rauf, M. O. (2013). Relationship between Perceived Organizational Justice and the Employees Job Satisfaction. Abasyn Journal of Social Sciences, 7(1), 100-117.

Sintha, D. K. (2013). Pengaruh Gaya Kepemimpinan Transformasional Terhadap 
Kepuasan Kerja Karyawan dan Komitmen organisasional Pada PT. KPM. Jurnal Manajemen, Strategi Bisnis Dan Kewirausahaan, 7(2), 116-125.

Siswanto, T. (2015). Pengaruh Budaya Organisasi Terhadap Komitmen Organisasional Karyawan Pada Sekolah Nusa Alam di Kabupaten Lombok Barat. Jurnal Valid, 12(3), 282-290.

Sousa, E. A. (2017). Pengaruh Kepemimpinan dan Motivasi Terhadap Komitmen Organisasional dan Dampaknya Pada Kualitas Layanan (Studi Pada Rumah Sakit Reverral Mubessi, Timor Leste). E-Jurnal Ekonomi Dan Bisnis Unud, 6(7), 2617-1634.

Suardani, N. M. D., \& Supartha, I. W. . (2018). Pengaruh Pemberdayaan, Kepemimpinan Transformasional, dan Keadilan Organisasional Terhadap Komitmen Organisasional Karyawan. E-Jurnal Manajemen Unud, 7(3), 1426-1451.

Usmany, T. P., Hamid, D., \& Utami, H. M. (2016). Pengaruh Budaya Organisasi Terhadap Komitmen Organisasional dan Kinerja Karyawan (Studi pada Karyawan Pabrik Condorukem, Ponorogo). Jurnal Administrasi Bisnis, 37(2), 38-44.

Wambui, L. N., \& Gichanga, L. (2018). The Impact of Organizational Culture on Organizational Commitment. Journal of Business \& Change Management, 5(2), 2076-2088.

Widyanto, R. L., \& Kartika, E. W. (2013). Pengaruh Kepuasan Kerja Terhadap OCB melalui Komitmen Organsasional Karyawan Cleaning Service di ISS Surabaya. Jurnal Hospitality Dan Manajemen Jasa, 1(1), 1-15.

Yudha, E. P., \& Hasib, F. F. (2014). Pengaruh Motivasi Terhadap Komitmen Organisasional Pada Guru Madrasah Ibtidaiyah Islamiyah Kota Madiun. Jurnal Ekonomi Syariah Teori Dan Terapan, 1(5), 305-323.

Yuliani, K. A. I., Sintaasih, D. K., \& Riana, I. G. (2016). Pengaruh Keadilan Organisasional Terhadap Kepuasan Kerja dan Komitmen Organisasional Pegawai Kontrak Fakultas Ekonomi dan Bisnis Universitas Udayana. Forum Manajemen, 14(1), 1-16.

Zefeiti, S. M. B. A., \& Mohamad, M. A. (2017). The Influence of Organizational Commitment on Omani Public Employees' Work Performance. EconJournals, 7(2), 151-160. 